\title{
The Effect of Length of Exposure to Computer- based Vocabulary Activities on Young Iranian EFL Learners' Vocabulary Gain
}

\author{
Karim Sadeghi \\ Urmia University, Iran \\ Masoumeh Dousti \\ Urmia University, Iran
}

\begin{abstract}
In recent years, research in the area of CALL and its role on teaching foreign languages has gained a strong foothold. This study was anattempt to explore the effectiveness of CALL technology in comparison to traditional book-based approach in teaching vocabulary to young Iranian EFL learners. As this study addressed young learners in an EFL context, it was supposed that time factor would play a crucial role in this regard. Hence, attending to the possible role of length of exposure to CALL technology was another objective followed in this study. To this end, one control and two experimental groups, with 15 participants in each group, took part in this study. The second experimental group used computer-based activities for 30 minutes, while the first one used them for 15 minutes. The experimental groups used Family and Friends 2 with its accompanying CD-ROM. This CD-ROM presentedcomputer-based vocabulary activities. To measure the degree of the participants' vocabularygain after the treatment sessions, a pre-test as well as a post-test were used.The results of one-way ANOVAs revealed that in the administration of the immediate post-test, the integration of computer-based activities did not have any significant effect on learners' vocabulary gain in general, and even no significant difference was noticed between the experimental groups. However, the findings of the delayed post-test showed the second experimental group performed significantly better than the other groups. The promising findings should call the teachers' and administrators' attention to take into consideration the integration of CALL technology into EFL classes.
\end{abstract}

Index Terms - computer-assisted language learning, computer-based activities, length of exposure, vocabulary teaching

\section{INTRODUCTION}

Technologies have been enhancing education most of the time and novel technologies have typically been used in education, particularly with the appearance of computer-related information technology (Devedzic, 2002). There exist some optimistic viewpoints toward the presence of technology in educational settings such as '1+1 is more than two'. It implies that the proper utilization of technology and an adept teacher can offer positive learning outcomes for learners.

Ramachaudran (2004) asserts that the application of new technological tools in language classes will be a great contribution to encourage and positively influence learners to use the target language. Among the technological tools, computer as the outstanding one is a big help in the improvement of language learning in numerous ways. As Arslan (2006) properly stated, presentation of learning activities in a stimulant rich environment can be more effective for teaching and learning, and computers are one of the tools that are capable of providing such an environment.

Considering the valuable merits of computer integration into EFL teaching, the potentiality of computers to present educational games and consequently adding fun to teaching and learning settings cannot be neglected. Quinn (2005) expresses the power of fun in classes and states that fun must be added to learning because learning will occur most effectively if learners' concentration and enthusiasm are attracted. Moreover, if learning is contextualized and the learner is required to offer a proper action, the learner easily realizes when and how to apply the target language.

While playing educational computer-based games, children have the opportunity to make mistakes and learn from their experiences without getting harmed. It is not an exaggeration to say that computer-based games are technological miracles that support learning. Being attention-grabbing and new, offeringmore desirableatmosphereand helping to keep the learners' attention on the task are believed to be the peculiar features of educational computer-based games (Heinich, Molenda, Russell, \&Smaldino, 2002). Gee (2003) argues that the potentiality of suitable computer-based games to let people have new experiences in the worlds created in games and at the same time to learn deeply are indicative of the importance of these games.

The instructive power of computer-based games for classroom use has been explored by some researchers (Dickey, 2005; Kafai, 2006; Jalali \& Dousti, 2012); however, the great role of games in improving learning is more obvious in their application in young learners' classes; in other words, their implementation in elementary education is a more 
promising area of research and practice in education (Warren, Dondlinger, \&Barab, 2008). Jessen (2001) discussed that computer-based games can be considered as part of children's everyday life which are absolutely integrated in modern child culture.

Taking into account all these advantages, designing appropriate games for educational purposes should be done with caution. In this regard, Nedomová (2007) highlights two major points for teachers. The first point relates to the application of games to keep the children alert and change the boring lessons to more attractive ones and the second one relates to the utilization of games to teach or learn specific parts of grammar, vocabulary, etc. This suggests that utilization of games in educational settings should be in line with educational purposes to improve learning.

Research has revealedthat retention of words is improved when they are presented in computer-assisted language learning (CALL) environments. This result is due to the fact that sounds, images, and even video that are provided in computer-enhanced environmentsgreatly contribute to the contextualization of the words (Akbulut, 2007; Hu \& Deng, 2007; Kim \& Gilman, 2008). Seferoglu (2006) believes the visuals provided in video games play a crucial role in the process of learning. He claims that the major part of learning takes place with the help of visual descriptions. According to Seferoglu (2006), visual elements:

a) attract the learner's attention and guides them,

b) keep their attention alive,

c) yield them to give emotional reactions,

d) formalize the concepts,

e) simplify complex concepts,

f) help to organize and perceive information by the use of geometric shapes,

g) easily connect the relations between a concept and its related elements by the use of organization flow charts,

h) give the chance to grasp some ideas which could be missed otherwise by some of the students (p.18).

Recent developments in audio, video, and computer techniques provide marvelous new chances for the inevitable infusion of technology into education. However, the particular focus of the research in the area of CALL should be the context in which it takes place. As it was stated, computers like any other teaching tools promise to be beneficial only if their practical use in a particular context is examined (Kern \& Warschauer, 2000). The peculiar role of context in the application of new technologies has been addressed by other researchers in the field too. As Egbert (2005) rightly says currently the differences in the contexts of CALL application is not addressed well while it is the most important point to be dealt with. This point of view is in line with the complaint made by Timucxin (2006) that the gap between the present literature regarding the utilization of computers in teaching settings and the actual application of them in EFL contexts is noticeable. Similarly, Huh and $\mathrm{Hu}$ (2005) highlight the important role of settings, learners, and events in CALL contexts and state that the profession could benefit from more description of the context. On the other hand, learners themselves play great roles in the process of language learning and teaching. Higgins and Johns (1984) call attentions to this point. They argue whether all students at all levels would benefit from computer-based activities or just one particular level of learners would take advantage of them.

Furthermore, a group of researchers questioned the effectiveness of games in general and computer games in particular to be integrated into educational settings. As some scholars have raised a concern (Facer, 2003; Kirriemuir\& McFarlane, 2004), there exist conflicting and limited number of researches addressing the usefulness of games in educational settings and their motivational roles in these settings. Wheeler (2009) claims that computer games are not useful for all group of learners and in all learning contexts unless they make the learning environments reliable and cooperative and it occurs when they are designed effectively.

Keeping in mind that very few studies have investigated the effectiveness of CALL in Iranian context and the newness of computers as teaching and learning instruments, more studies are welcome in this area. Given the widespread interest in using CALL across various settings and a variety of age and proficiency levels in EFL/ESL contexts, this study applied the technology to a less-touched focus group, i.e. young learners in an EFL setting. Considering various variables that might account for differences in the performance of young learners exposed to CALL, length of exposure seemed to be one of the influential factors that deserved investigation. Hence the study sought to address the effect of computer-based activities on learners' vocabulary gain while attending to length of exposure to these activities in particular.

The following questions were formulated to address the above objectives:

Q1: Does the integration of computer-based vocabulary activities have any significant effect on young Iranian elementary EFL learners' vocabulary gain?

Q2: Does the length of exposure to computer-based vocabulary activities have any significant effect on young Iranian elementary EFL learners' vocabulary gain?

Q3: Does the integration of computer-based vocabulary activities have any significant long-term effect on young Iranian elementary EFL learners' vocabulary gain?

Q4: Does the length of exposure to computer-based vocabulary activities have any significant long-term effect on young Iranian elementary EFL learners' vocabulary gain?

Accordingly, the following hypotheses were formulated to be tested at the probability level of 0.05 : 
H1: The integration of computer-based vocabulary activities does not have any significant effect on young Iranian elementary EFL learners' vocabulary gain.

$\mathrm{H} 2$ : The length of exposure to computer-based vocabulary activities does not have any significant effect on young Iranian elementary EFL learners' vocabulary gain.

H3: The integration of computer-based vocabulary activities does not have any significant long-term effect on young Iranian elementary EFL learners' vocabulary gain.

H4: The length of exposure to computer-based vocabulary activities does not have any significant long-term effect on young Iranian elementary EFL learners' vocabulary gain.

\section{Methodology}

\section{A. Participants}

In order to obtain the required data to properly answer the research questions, 49 female elementary EFL learners, who constituted three intact classes, were involved in the research process. They were within the age range of 11-13 and according to the classification of the language school, their proficiency level was FLC7 (First Language Course), which was a categorization to address young teenager learners' language proficiency level. Although they were all supposed to have a similar level of general proficiency in English, Cambridge Young Learners English Test was utilized to assure about their homogeneity in terms of their proficiency level. This test includes three examination papers from University of Cambridge ESOL examinations. The mean score of 60.82, 62, and 62.44 for the first, second, and third groups was observed after the analysis of the gained data. However four outliers, who got extreme scores in comparison to the rest of participants, were omitted from the study and the results revealed that all the other participants could be considered as beginners with more or less the same proficiency level. Hence all of these participants were qualified to serve the purpose of the research. Following a semi-randomization procedure, the intact classes were assigned to two experimental groups and one control group. It is worth mentioning that 15 participants were present in each of these groups.

\section{B. Instruments}

The following instruments were used in this study for data elicitation purposes.

\section{Cambridge young learners English test}

Cambridge Young Learners English Test was utilized to assure about the homogeneity of the participants with regard to their language proficiency. This test has been developed to assess the proficiency level of elementary learners within the age range of 7 to 12 while adding entertaining elements to testing. The updated edition of 2007 was utilized in the present study. This edition, taken from the University of Cambridge ESOL Examinations, was considered to be appropriate for learners within the age range of 9 to 12. Appealing activities and eye-catching pictures utilized to increase young learners' motivation are peculiar features of this test pamphlet. The first test from this edition was chosen on the basis of researcher's familiarity with the language school's educational system as well as learners'current level of English. The test focused on allof the four skills. In the first section, 25 listening questions were included in five parts.Reading and writing were addressed in the second part which presented 35 questions in seven parts; itshould be mentioned that writing section followed objective scoring.Three types of tasks named as find the difference, information exchange, and tell the story checked participants' speaking ability. 30 learners comparable to the target members in terms of their language proficiencytried their answers to assess the reliability of this test. The results of KR21 demonstrated 0.76 degree of the reliability for the test, which was a satisfactory one.

\section{Achievement test}

An achievement test was developed by two teachers to be used as post-test with the aim of assessing participants' vocabulary gain after the implementation of computer-based activities. The teachersinvolved in the process of test development were both familiar with the aim of test and the content of the lessons.Also, another teacher reviewed all the items to identify any mistakes and to add to the quality of the test. The test consists 25 items in the form of fillin the blanks andopen-ended questions. Since only one answer would be correct for each of the items, they were scored objectively. The content validity of the test was checked taking into account the table of specifications by two other experts. Following this review and problem solving stages, the test was piloted on 30 peerlearners whom possessed the same level of proficiency, age range, and gender as the target group. KR-21 method was applied to examine the reliability of the test and the results showed a desirable degree of reliability, e.g. 0.68.

\section{Family and Friends 2}

Family and Friends 2 published by Cambridge University Press was used in all three classes. The outstanding feature of the Family and Friends series is its studentMultiRom with computer-based vocabulary activities presented for each unit. The quality of these activities is improved using interestingpictures and sounds. In the vocabulary part, the students are required to match the words with pictures and then software checks the given responses to the activities and expressions such as 'Congratulations' or 'Try Again' are provided to indicate participants' success in doing these activities. Using these expressions, the software presented a kind of instant feedback. Although this book was taught in all the classes, the computer-based activities were only used as post-teaching activities in experimental groups in different ways.It was assured that the control group did not receive the book's accompanying software. 


\section{Procedure}

To investigate the potential effects of using computer-based activities on young learners' vocabulary gain, the following steps were followed:

At first to address the homogeneity of the involved participants within the intact classes, Cambridge Young Learners' English test was administered. This test checked the proficiency level of 49 elementary young female EFL learners in three different sessions. The decision to conduct this test on three separate sessions was made on the basis of the possible negative effect of learners' short attention span on the reliability of the obtained data. Hence reading and writing in one session and each of the listening and speaking partsin two separate sessionswere administered. To avoid any violation to the reliability of the test scores for the speaking part, two raters provided their scores for each participant. Then inter-rater reliability was checked and a high correlation between the two sets of scores was noticed, 0.81. However, in the process of examining participants' generalproficiency level, four outliers were observed and consequently excluded from the study. After this homogenizing step, a semi-randomization procedure was followed to randomly assign the classes to one control and two experimental groups, with 15 participants in each group.

In the treatment sessions, the book was taught in the control group without the application of the computer software. However, this group took advantage of paper-based activities. These activities were similar to the practiced computerbased activities in the experimental groups in terms of their content. These activities were deliberately used to be sure about the adequate exposure of the control group to the same vocabulary as the othertwo groups. These activities were distributed as immediate post-teaching activities in the 12 sessions of treatment. Each session, participants had the time limit of 15 minutes to answer these activities. It must be mentioned that each session participants made groups of four to work on these activities, however due to the number of participants there was always a group of three.

Both of the experimental groups utilized the computer software as post-teaching activities in their classes. Length of exposure was the only differential feature between the two experimental groups. The length of exposure for the second experimental group was twice as long as the first experimental group; the first experimental group used the computer activities fifteen minutes and the second experimental group used them thirty minutes. Each of the participants tried their answers for the presented computer-based vocabulary activities in their groups, then they were supposed to check their answers and if the correct answer was not provided, the participants had to repeat the activity. It must be emphasized that the used MultiRom was only accessible in the classes.

Finally, the achievement test was administered to compare the performance of all groups and to diagnose any possible effects of computer-based activities on improving young learners' vocabulary gain after the treatment sessions.

To get a better understanding of treatment effects and to evaluate longer-term effects of the utilization of computerbased activities, the same test used in immediate post-test was also utilized as delayed post-test two weeks later. It is worth mentioning that the total score of the test was 25 .

\section{Data Analysis}

Statistical Package for Social Sciences (SPSS) software was used for the analysis of the data. To address the questions concerning the effectiveness of computer-based activities, a one way ANOVA was utilized. Moreover, an independent $t$-test was used to examine whether length of exposure to computer-based activities has any significant effect on learners' vocabulary gain. To gauge the long-term effects of computer-based activities using the results of delayed post-test, the same data analysis procedures were followed.

\section{RESUltS AND DisCUSSION}

\section{A. The Results of Proficiency Test}

As it was stated earlier, Cambridge Young Learners English Test was used to check the participants' homogeneity in the intact classes. To do so, a one way ANOVA was run. Table 3.1 provides the information related to this analysis.

TABLE 3.1

DESCRIPTIVE STATISTICS FOR PRE-TEST PROFICIENCY TEST

\begin{tabular}{|c|c|c|c|c|c|c|c|c|}
\hline & \multirow[b]{2}{*}{$\mathrm{N}$} & \multirow[b]{2}{*}{ Mean } & \multirow[b]{2}{*}{ Std. Deviation } & \multirow[b]{2}{*}{ Std. Error } & \multicolumn{2}{|c|}{ 95\% Confidence Interval for Mean } & \multirow[b]{2}{*}{ Minimum } & \multirow[b]{2}{*}{ Maximum } \\
\hline & & & & & Lower Bound & Upper Bound & & \\
\hline first class & 17 & 60.82 & 7.88 & 1.91 & 56.77 & 64.88 & 40 & 70 \\
\hline third class & 16 & 62.44 & 5.16 & 1.29 & 59.69 & 65.19 & 47 & 68 \\
\hline Total & 49 & 61.73 & 6.19 & .88 & 59.96 & 63.51 & 40 & 70 \\
\hline
\end{tabular}

In table 3.2 , the significance value is 0.37 which means that the homogeneity of variances is not violated. 
TABLE 3.2

\begin{tabular}{llcc}
\multicolumn{5}{c}{ TABLE 3.2} \\
TEST OF HOMOGENEITY OF VARIANCES FOR PRE-TEST \\
Levene Statistic & df1 & df2 & Sig. \\
\hline .99 & 2 & 46 & .37
\end{tabular}

In the following step, the presence of significant difference is examined among the intact classes. No significant difference at the $p<.05$ level in pre-test scores for the present intact classes was observed: $F(2,46)=.29, p=.74$. The results revealed that all of these groups have similar proficiency level at the outset of the study; therefore the results of the achievement test are comparable (Table 3.3).

TABLE 3.3

ANOVA FOR PRE-TEST SCORES

\begin{tabular}{|c|c|c|c|c|c|}
\hline \multicolumn{6}{|c|}{ AINU V A FOR PRE-IEST SCURES } \\
\hline & Sum of Squares & Df & Mean Square & $\mathrm{F}$ & Sig. \\
\hline Between Groups & 23.14 & 2 & 11.57 & .29 & .74 \\
\hline Within Groups & 1818.40 & 46 & 39.53 & & \\
\hline Total & 1841.55 & 48 & & & \\
\hline
\end{tabular}

However, on the basis ofthe box plot which demonstrates the presence of four outliers, the aforementioned participants' performance was not taken into account in the analysis of the rest of the data (Figure 3.1).

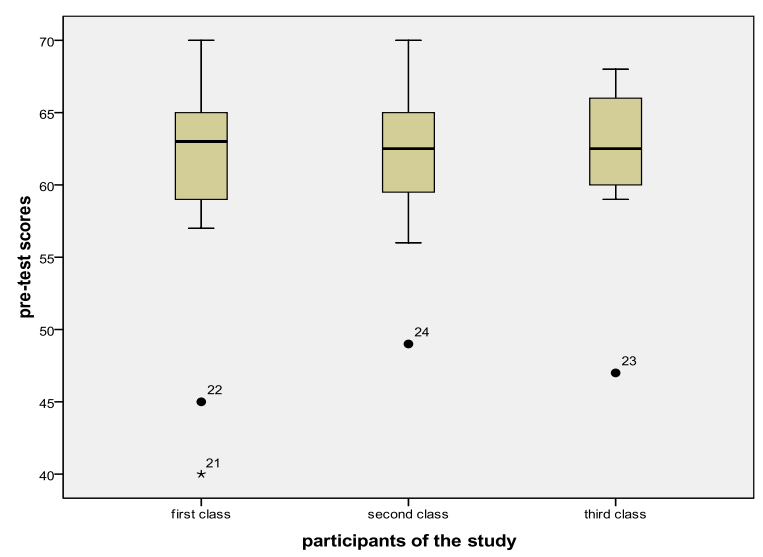

Figure 3.1 Box plot for Pre-test

\section{B. Computer-based Activities and Vocabulary Gain}

This study attempted to investigate the effectiveness of computer-based activities in improving participants' vocabulary gain. Furthermore, the length of exposure was also focused on to determine its effect on vocabulary gain. To find the answer for the first question mentioned above, a one-way ANOVA was utilized. But at first, the mean scores and the other descriptive statistics for all groups on this variable are presented below (see Table 3.4).

TABLE 3.4

DESCRIPTIVE STATISTICS FOR VOCABULARY POST-TEST

\begin{tabular}{|c|c|c|c|c|c|c|c|c|}
\hline & \multirow[b]{2}{*}{$\mathrm{N}$} & \multirow[b]{2}{*}{ Mean } & \multirow[b]{2}{*}{ Std. Deviation } & \multirow[b]{2}{*}{ Std. Error } & \multicolumn{2}{|c|}{ 95\% Confidence Interval for Mean } & \multirow[b]{2}{*}{ Minimum } & \multirow[b]{2}{*}{ Maximum } \\
\hline & & & & & Lower Bound & Upper Bound & & \\
\hline Control & 15 & 10.80 & 2.17 & .56 & 9.59 & 12.01 & 7 & 15 \\
\hline experimental1 & 15 & 10.73 & 1.38 & .35 & 9.97 & 11.50 & 9 & 13 \\
\hline experimental2 & 15 & 11.00 & 1.69 & .43 & 10.06 & 11.94 & 8 & 15 \\
\hline Total & 45 & 10.84 & 1.74 & .26 & 10.32 & 11.37 & 7 & 15 \\
\hline
\end{tabular}

To ensure that the homogeneity of variances is not violated, first the significance value in Table 3.5 is checked and since the significance value is 0.36 , the homogeneity of variances is not violated.

TABLE 3.5

TEST OF HOMOGENEITY OF VARIANCES FOR VOCABULARY POST-TEST

\begin{tabular}{llll} 
Levene Statistic & df1 & df2 & Sig. \\
\hline 1.03 & 2 & 42 & .36
\end{tabular}

One-way ANOVA was applied to identify the presence of any significant difference among the groups. The results show that there is no significant difference at the $p<.05$ level in vocabulary post-test scores for the three groups: $F(2$, $42)=.09, p=.91$. Table 3.6 presents the already mentioned results in detail. 


\begin{tabular}{llllll}
\multicolumn{7}{c}{ TABle 3.6 } \\
& Sum of Squares & Df & Mean Square & F & Sig. \\
\hline Between Groups & .57 & 2 & .28 & .09 & .91 \\
\hline Within Groups & 133.33 & 42 & 3.15 & & \\
\hline Total & 133.91 & 44 & &
\end{tabular}

\section{Length of Exposure to Computer-based Activities and Vocabulary Gain}

Though no difference between the experimental groups is observed in the previously discussed statistics, for triangulation purposes, a separate $t$-test was run. Checking the assumptions for the equality of variances shows that the significant value is .95 that is greater than .05; the equality of variances is assumed. Hence, the first line is checked and the value of Sig. (2-tailed) is .64 that is above .05; this result implies no significant difference between the mean scores of the experimental groups (see Table 3.7)

TABLE 3.7

INDEPENDENT SAMPLEST-TEST FOR VOCABULARY POST-TEST

Levene's Test for

Equality of Variances t-test for Equality of Means

\begin{tabular}{|c|c|c|c|c|c|c|c|c|c|c|}
\hline & & & & & & & & & \multicolumn{2}{|c|}{$\begin{array}{l}95 \% \text { Confidence Interval } \\
\text { of the Difference }\end{array}$} \\
\hline & & $\mathrm{F}$ & Sig. & $\mathrm{t}$ & df & $\begin{array}{l}\text { Sig. (2- } \\
\text { tailed) }\end{array}$ & $\begin{array}{l}\text { Mean } \\
\text { Difference }\end{array}$ & $\begin{array}{l}\text { Std. Error } \\
\text { Difference }\end{array}$ & Lower & Upper \\
\hline \multirow[t]{2}{*}{$\begin{array}{l}\text { vocabulary } \\
\text { post-test }\end{array}$} & $\begin{array}{l}\text { Equal variances } \\
\text { assumed }\end{array}$ & .00 & .95 & -.47 & 28 & .64 & -.26 & .56 & -1.42 & .89 \\
\hline & $\begin{array}{l}\text { Equal variances } 1 \\
\text { assumed }\end{array}$ & & & -.47 & 26.97 & .64 & -.26 & .56 & -1.42 & .89 \\
\hline
\end{tabular}

\section{Longer-term Effects of Computer-based Vocabulary Activities on Vocabulary Gain}

In this section, the longer-term effect of computer-based activities on learners' vocabulary gain is examined. At first, the descriptive statistics is presented to offer detailed information about the present groups. Table 3.8 provides the mentioned information.

TABLE 3.8

DESCRIPTIVE STATISTICS FOR VOCABULARY DELAYED POST-TEST

\begin{tabular}{|c|c|c|c|c|c|c|c|c|}
\hline & \multirow[b]{2}{*}{$\mathrm{N}$} & \multirow[b]{2}{*}{ Mean } & \multirow[b]{2}{*}{ Std. Deviation } & \multirow[b]{2}{*}{ Std. Error } & \multicolumn{2}{|c|}{$95 \%$ Confidence Interval for Mean } & \multirow[b]{2}{*}{ Minimum } & \multirow[b]{2}{*}{ Maximum } \\
\hline & & & & & Lower Bound & Upper Bound & & \\
\hline Control & 15 & 10.27 & 1.66 & .43 & 9.34 & 11.19 & 7 & 13 \\
\hline experimental1 & 15 & 10.60 & 1.72 & .44 & 9.65 & 11.55 & 8 & 13 \\
\hline experimental2 & 15 & 12.60 & 1.72 & .44 & 11.65 & 13.55 & 10 & 15 \\
\hline Total & 45 & 11.16 & 1.96 & .29 & 10.57 & 11.75 & 7 & 15 \\
\hline
\end{tabular}

The homogeneity of variances was checked and as Table 3.9 demonstrates, the significance value is .85 which is greater than .05 , so this assumption is not violated.

TABLE 3.9

TEST OF HOMOGENEITY OF VARIANCES FOR VOCABULARY DELAYED POST-TEST

\begin{tabular}{llcc} 
Levene Statistic & df1 & df2 & Sig. \\
\hline .15 & 2 & 42 & .85
\end{tabular}

Following this step, a one-way ANOVA was used to compare mean differences between groups as far as vocabulary long-term gain was concerned. The results of the analysis reveal that there is a significant difference at the $p<.05$ level in vocabulary delayed post-test scores for the three groups: $F(2,42)=8.21, p=.00$ (see Table 3.10).

TABLE 3.10

ANOVA VOCABULARY DELAYED POST-TEST

\begin{tabular}{lccccc} 
& Sum of Squares & Df & Mean Square & F & Sig. \\
\hline Between Groups & 47.77 & 2 & 23.88 & 8.21 & .00 \\
\hline Within Groups & 122.13 & 42 & 2.90 & & \\
\hline Total & 169.91 & 44 & &
\end{tabular}

To check where the exact place of the difference was, post-hoc Tukey HSD test was used. The comparisons showed that control group $(M=10.27, S D=1.66)$ did not differ significantly from first experimental group $(M=10.60, S D$ 
=1.72). However, the mean score for control group $(M=10.60, S D=1.66)$ was significantly different from the second experimental group $(M=12.60, S D=1.72)$. Furthermore, the first experimental grope $(M=10.60, S D=1.72)$ was significantly different from the second experimental group $(M=12.60, S D=1.72)$. The mean difference for the groups is compared at $p<.05$ (see Table 3.11).

TABLE 3.11

MULTIPLE COMPARISONS FOR VOCABULARY DELAYED POST-TEST

\begin{tabular}{|c|c|c|c|c|c|c|}
\hline \multirow[b]{2}{*}{ (I) groups } & \multirow[b]{2}{*}{ (J) groups } & \multirow[b]{2}{*}{ Mean Difference (I-J) } & \multirow[b]{2}{*}{ Std. Error } & \multirow[b]{2}{*}{ Sig. } & \multicolumn{2}{|c|}{ 95\% Confidence Interval } \\
\hline & & & & & Lower Bound & Upper Bound \\
\hline \multirow[t]{2}{*}{ Control } & experimental1 & -.33 & .62 & .85 & -1.85 & 1.18 \\
\hline & experimental2 & $-2.33^{*}$ & .62 & .00 & -3.85 & -.82 \\
\hline \multirow[t]{2}{*}{ experimental1 } & Control & .33 & .62 & .85 & -1.18 & 1.85 \\
\hline & experimental2 & $-2.00^{*}$ & .62 & .00 & -3.51 & -.49 \\
\hline \multirow[t]{2}{*}{ experimental2 } & Control & $2.33^{*}$ & .62 & .00 & .82 & 3.85 \\
\hline & experimental1 & $2.00^{*}$ & .62 & .00 & .49 & 3.51 \\
\hline
\end{tabular}

\section{E. Longer Term Effects of Length of Exposure to Computer-based Activities on Vocabulary Gain}

Though the presence of significant difference was observable in the above discussion of results, a separate $t$-test was run for triangulation purposes. Since the significant value is .79 that is greater than .05 , the equality of variances is assumed. The value of the Sig. (2-tailed) in the equal variances assumed line is less than .05 that means there is significant difference in the mean scores on the dependent variable for each of the experimental groups (see Table 3.12).

TABLE 3.12

INDEPENDENT SAMPLEST-TEST FOR VOCABULARY DELAYED POST-TEST

Levene's Test for

Equality of Variances t-test for Equality of Means

\begin{tabular}{|c|c|c|c|c|c|c|c|c|c|c|}
\hline & & & & & & & & & \multicolumn{2}{|c|}{$\begin{array}{l}95 \% \text { Confidence } \\
\text { Interval of the } \\
\text { Difference }\end{array}$} \\
\hline & & $\mathrm{F}$ & Sig. & $\mathrm{t}$ & df & $\begin{array}{l}\text { Sig. (2- } \\
\text { tailed) }\end{array}$ & $\begin{array}{l}\text { Mean } \\
\text { Difference }\end{array}$ & $\begin{array}{l}\text { Std. Error } \\
\text { Difference }\end{array}$ & Lower & Upper \\
\hline \multirow[t]{2}{*}{$\begin{array}{l}\text { vocabulary } \\
\text { delayed post-test }\end{array}$} & $\begin{array}{l}\text { Equal variances } \\
\text { assumed }\end{array}$ & .06 & .79 & -3.17 & 28 & .00 & -2.00 & .62 & -3.28 & -.71 \\
\hline & $\begin{array}{l}\text { Equal variances not } \\
\text { assumed }\end{array}$ & & & -3.17 & 28.00 & .00 & -2.00 & .62 & -3.28 & -.71 \\
\hline
\end{tabular}

\section{F. Computer-based Activities and Young Learners' Vocabulary Gain}

Once more, the results of the analysis of the obtained data for vocabulary gain in the application of compute-based activities are briefly presented in this section. The results demonstrated that in the administration of the immediate posttest, the integration of computer-based activities did not have any significant effect on young Iranian elementary EFL learners' vocabulary gain in general, and even no significant difference was noticed between the experimental groups. However, the findings of delayed post-test were different from those of the immediate post-test. Though no significant difference was seen between the control group and the first experimental group, the control and the second experimental group performed significantly different in the favor of the application of computer-based activities. The length of exposure was also influential in that the second experimental group had significantly higher means in comparison to that of the first one in the delayed post-test stage.

The results of the immediate post-test suggest that even paper-based pictures can help to acquire the new words as effectively as computer-based pictures though computer-based materials were enhanced with sound and color. The idea of the effectiveness of paper-based pictures is supported in Akbari's (2008) investigation. His comparison between the control, picture-based, and context-based groups revealed that both picture and context enhanced the vocabulary development of the learners, though picture-based group outperformed both paper-based and context-based groups. It may be due to the fact that for short term retention of words, even black and white paper-based pictures are influential.

As stated earlier, the second experimental group with longer length of exposure outperformed the other groups. Similar studies support this finding. For example, Hu and Deng (2007), Kim and Gilman (2008), and Akbulut (2007) reported the improvement of word retention in CALL environments because it places the words in context. Tamjid and Aghlara (2011) reported similar findings. They aimed to find out whether Iranian young learners' vocabulary learning promotes through the application of digital computer games. They ran independent samples $t$-test to compare the performance of the control and experimental groups. The analysis of the obtained data showed the outperformance of the experimental group as they got higher mean scores. This finding is an evidence of the positive effect of integration of computer-based games in vocabulary teaching. 
Likewise, Ghabanchi and Anbarestani (2008) focused on the improvement of learners' vocabulary learning in computer-enhanced teaching environments. They related learners' long-term retention of words to the intensive mental processing that took place in CALL classes. Not only vocabulary learning was boosted, but also better pronunciation was observed. It must be mentioned that in the immediate test the control group considerably outperformed the experimental one. However, the scores of the experimental group were significantly higher in the delayed test.

Segers and Verhoeven (2003) reported the same positive results in their study. They utilized computers for intensive vocabulary training. This study, which was conducted in a kindergarten in the Netherlands, lasted for two years and at the end of the treatment the experimental group's good performance was observed.Tsou, Wang, and Li (2002) also studied the possible effects of CALL integrationon elementary learners' English abstract words learning in southern Taiwan. The results revealed that more abstract words were acquired by the experimental group in comparison to the control group. In the support of the present findings, Barani, Mazandarani, and Rezaie (2010) examined whether young Iranian EFL learners' vocabulary learning would increase through the utilization of audiovisual aids. It was interesting to find out that the experimental group's mean scores differed significantly from pre-test to post-test in the favor of the integration of audiovisual aids. Sabet and Shalmani' study (2010) compared the vocabulary gain of two groups. In the treatment for the first group, the items were taught using visual texts and video, while the second group used spoken texts and video. The obtained result showed better performance of the first group.

In Seferoglu's study (2006), the power of the colorful images accompanied with sound in teaching vocabulary was noticed.Learners' improved vocabulary learning was attributed to the presentation of the target words through multimedia materials. He highlights that the visual elements called learners' attention, guided them, kept them attentive and at the end formalized the presented words.

Furthermore,Huyen and Nga (2003) argue that games are helpful in teaching vocabulary. They found that the application of games did not lead to any signinfant difference in the performance of groups in the immediate post-test, however better retention of the words was seen in a longer period of time. They attribute their finding to the contextualization of vocabulary in the application of games. Moreover, they believe that better vocabulary gain occurs during the process of learning, practicing, and reviewing it in a pleasant atmosphere.They cited relaxed atmosphere, competitive but friendly environment, and contextualization as the key elements in gaining the optimistic results in their study.

\section{CONCLUSION}

As the aforementioned results demonstrated, the overall effectiveness of the application of computer-based activities in the Iranian context is proved in this study. Furthermore, it was found that with longer length of exposure better results were achieved. Hence, the amount of time devoted to the use of these activities in elementary classes should be concentrated on to achieve better results. Taking into account these promising findings, more effort should be put on the integration of CALL to EFL settings in general and elementary EFL classes in particular.

One of the major implications of the present study is for teachers. Considering the increase of motivation that was observed on the part of the learners in the experimental groups, this may be a good clue for teachers to utilize more computer-based activities in their classes. One of the reasons for such a boost in learners' motivation was the experience of such new learning equipments in their EFL classes. While paper-based activities were done with the least enthusiasm in the control group, the computer-based activities encouraged all learners in both of the experimental groups. To some extent, the presence of such motivation was due to the sound, music, and colorful images that were utilized in designing these games. Furthermore, these computer-based activities were game like; and consequently, they involved all learners, especially passive ones, in the process of learning. The application of these activities changed almost all learners to active and attentive participants in the class. Hence, teachers are recommended to apply new technologies in their classes which will lead to teaching and learning language successfully.

The other implication for teachers is creating a sense of group work among learners. They had time to work together, discuss the answers in their groups, and sometimes they did their best to convince each other and justify their answers. Furthermore, peer correction provided a more relaxed environment to improve learners' gain. It improved the presence of cooperation among learners.

As a final remark, although CALL application is still in its infancy in Iranian context, its unquestionable advantages intrigue teachers to apply it in their classes.

Finally in this section, some research areas are proposed for further scrutiny.First, this study focused on vocabulary as the dependent variable on which the effect of length of exposure to computer-based activities as the independent variable was examined.Other areas of language that are worth being investigated, fore example four main skills can be focused on in the application of CALL in educational settings. Second, further studies should be conducted to examine whether gender is also influential in the effectiveness of computer-enhanced classes or not. Third, as this study only addressed young elementary learners' achievement, exploring other proficiency levels and different age ranges will provide better insights on the issue. Fourth, computer-based activities may be good to be used as home assignments. Hence, their effectiveness outside the class is worth examination. Fifth, further research is necessary to examine the more subtle differences among learners because some experienced learners may find some of the educational games too simple and boring. 


\section{REFERENCES}

[1] Aghlara,L., \&Tamjid,N.(2011). The effect of digital games on Iranian children' vocabulary retention in foreign language acquisition. Procedia Social and Behavioral Sciences, 29, 552-560.

[2] Akbari, O. (2008).Teaching vocabulary items through contextualization and picture to elem-entary Iranian EFL students. Asian EFL Journal, 10(3), 53-77.

[3] Akbulut, Y. (2007). Effects of multimedia annotations on incidental vocabulary and reading comprehension of advanced learners of English as a foreign language. Journal of Instruc-tionalScience, 35, 499-517.

[4] Arslan, A. (2006). The Attitude scale toward making computer supported education. YüzüncüYil University, Journal of the Faculty of Education, 2 (2), 34-43.

[5] Barani, G., Mazandarani, O., \&Rezaie, H. (2010). The effect of application of picture into picture audio- visual aids on vocabulary learning of young Iranian ELF learners. Procedia Social and Behavioral Sciences, 2, 5362- 5369.

[6] Devedzic, V. (2002). What does current web-based education lack? Proceedings of the IASTED International.Conference. Applied Informatics, Austria, 351-607.

[7] Dickey, M. (2005). Engaging by design: How engagement strategies in popular computer and video games can inform instructional design. Educational Technology Research \& Development, 53 (2), 67-83.

[8] Egbert, J. (2005). Conducting research on CALL. In J. Egbert, \& G. Petrie (Eds.), Research perspectives on CALL Mahwah (pp. 3-8). New Jersey: Laurence Erlbaum Associates.

[9] Facer, K. (2003).Computer games and learning. Retrieved October 19, 2011from $\mathrm{http} / / / \mathrm{www}$.futurelab.org.uk/resources/documents/ discussion papers/ Computer Games and Learning discpaper.pdf.

[10] Gee, J. P. (2003). What video games have to teach us about learning and literacy.ACMCom-puters in Entertainment, 1(1), 1-3.

[11] Ghabanchi, Z., \&Anbarestani, M. (2008). The effects of call program on expanding lexical knowledge of EFL Iranian intermediate learners. The Reading Matrix, 8 (2), 86-95.

[12] Heinich, R., Molenda, M., Russell, J. D., \&Smaldino, S. E. (2002).Instructional media and technologies for learning. New Jersey: Merrill Prentice Hall.

[13] Higgins, J., \& Johns, T. (1984). Computers in Language Learning. Reading Addison-Wesley Publishing Division.

[14] Hu, H. P., \& Deng, L. J. (2007).Vocabulary acquisition in multimedia environment. US China Foreign Language, 5(8), 55-59.

[15] Huh, K.,\& Hu, W. (2005). Criteria for effective CALL research.In J. Egbert, \& G. Petrie (Eds.), Research Perspectives on CALL Mahwah (pp. 9-21). New Jeresy: Laurence Erlbaum Associates.

[16] Huyen, N.T.T., \&Nga, K.T.T. (2003). Learning vocabulary through games: The Effectiveness of learning vocabulary through games. Asian EFL Journal: English

[17] Language Teaching and Research Articles. Retrieved November13, 2011 from http://www.asian-efl-journals.com.

[18] Jalali, S., \& Dousti, M. (2012).Vocabulary and Grammar Gain Through Computer Educational Games. GEMA Online ${ }^{\mathrm{TM}}$ Journal of Language Studies, 12(4), 1077-1088.

[19] Jessen, C. (2001). Children, play and computer games. Odense: Centeret.

[20] Kafai, Y. (2006). Playing and making games for learning: Instructionist and constructionist perspectives for game studies. Games and Culture, 1(1), 36-40.

[21] Kern, R., \&Warschauer, M. (2000). Introduction: Theory and practice of networked-based language teaching. In M. Warschauer, \& R. Kern (Eds.), Network-based language teaching: Concepts and practice (pp.1-19). New York: Cambridge University Press.

[22] Kim, D., \& Gilman, D. A. (2008). Effects of text, audio, and graphic aids in multimedia instruction for vocabulary learning. Educational Technology \& Society, 11(3), 114-126.

[23] Nedomová, A. (2007). Teaching grammar to young learners. Unpublished master thesis, Masaryk University, Czech Republic. Retrieved December 21, 2011 from http://is.muni.cz/.

[24] Quinn, C. (2005). Engaging Learning. San Francisco: Pfeiffer.

[25] Ramachaudran, S. (2004). Integrating new technologies into language teaching: Two activities for an EAP classroom. TESL Canada Journal, 22 (1), 79 - 90.

[26] Sabet, M., \&Shalmani, H. (2010). Visual and spoken texts in MCALL courseware: The effects of text modalities on the vocabulary retention of EFL learners. English Language Teaching, 3(2), 30-36.

[27] Seferoglu, S. S. (2006). Ogretimteknolojilerivematerial tasarimi (p. 18). Ankara: Pegem AkademiYayincilik.

[28] Segers, E., \&Verhoeven, L. (2003).Effects of vocabulary training by computer in kindergarten. Journal of Computer Assisted Learning, 19, 557-566.

[29] Timucin, M. (2006).Implementing CALL in an EFL context.ELT Journal, 60(3), 262-269.

[30] Tsou, W., Wang, W., \& Li, H. (2002). How computers facilitate English foreign language learners acquire English abstract words. Computers \& Education, 39, 415-438.

[31] Warren, S. J., Dondlinger, M. J., \&Barab, S. A. (2008). A MUVE towards PBL writing: Effects of a digital learning environment designed to improve elementary student writing. Journal of Research on Technology in Education, 41 (1), 113140 .

Karim Sadeghi has a PhD in TESOL from the University of East Anglia (UK) and is an academic staff member of Urmia University, Iran. In addition to serving as an editorial board member of a couple of national and international journals, he is also the editor in chief of Iranian Journal of Language Teaching Research. He was selected as Iran's top researcher in Humanities and Social Sciences in 2013. 
Masoumeh Dousti has an MA in ELT MA from Urmia University. Her research interests are computer-assisted language learning, educational technology, and teaching English as a foreign language. 